\title{
Student Performance Measurement on Psychometric Parameters
}

\author{
Iti Burman, Amity University, Noida, India \\ https://orcid.org/0000-0002-9598-1467 \\ Subhranil Som, Amity University, Noida, India \\ Syed Akhter Hossain, Daffodil International University, Bangladesh \\ Mayank Sharma, Amity University, Noida, India
}

\begin{abstract}
Educational data mining provides various advantages to the education systems in many ways. It enhances the teaching process, the learning process, the scholastic performance of students, career selection, employability, and more. The differences in attitude of students' behavior lead to difference in their academic performance. The article covers the non-intellectual parameters of students to enhance their academic performance. The study tests the relationship between psychometric constructs of students and their academic correlate. The models for enhancing intellectual performance which involves various non-intellectual parameters are analyzed using structural equation modeling. It is observed that the values of the models were retrieved near to fit values. The results entail that the models will be beneficial for students in improving their academic performance by revising their psychological parameters.
\end{abstract}

\section{KEYWORDS}

Academic Performance, Educational Data Mining, Multivariate Analysis, Psychometric Measures, Structured Equation Modeling, Student

\section{INTRODUCTION}

The differences in students' behavior impact their intellectual performance. Students differ in their learning styles like kinesthetic learners referring to learning by immersing in projects, aural learners, analytical learners and global learners adopting stimulations. Evidences have shown that nonintellectual parameters are highly associated with academic performance of students. The relationship between intelligence, personality, and interests; have been depicted by (Ackerman \& Heggestad, 1997), also the impact of personality five factor model on intellectual performance is discussed by (Poropat, 2009). Factors involving self-regulatory learning strategies, motivation and style of learning also impact academic performance of students (Chamorro-Premuzic \& Furnham, 2008). (Hamsa, Indiradevi \& Kizhakkethottam, 2016) worked on scholastic parameters of undergraduate and graduate students like admission time, submission date of assignment, daily attendance, conduction 
of examination on scheduled time; to predict their academic performance. Self-regulatory learning strategies (SRLS) and motivation accentuate in recent years. In current era SRLS have become core skill (Anderson Koenig, 2011). Also, SRLS and motivation are not ordinarily included in classroom teaching or lecture and henceforth becomes an important aspect in students learning (Cleary, Gubi, \& Prescott, 2010; Wehmeyer, Agran, \& Hughes, 2000). The data mining in the field of education is useful at all stages of learning. In schools the students often find challenges while transiting from elementary studies as they differ in expectations and demands (Grolnick \& Raftery-Helmer, 2015). In (Shahiri \& Husain, 2015) the data mining approaches are applied on psychometric parameters comprising of personality, motivation and learning strategies. The contribution of extracurricular activities and soft skills is discussed in addition to psychometric parameters by (Mishra, Kumar \& Gupta, 2014) to measure the scholastic performance of students.

Students lacking in motivation, SRLS and cognitive abilities are incapable of facing academic challenges especially during absenteeism in classes or lectures, in completing multiple assignments and preparing for examination (Blackwell, Trzesniewski \& Dweck, 2007; Butler, Beckingham \& Lauscher, 2005; Dignath \& Büettner, 2008). Learners belonging to low socio-economic status ordinarily deficit in motivation constructs and interpretations (Byrnes, 2003; Steele, 1997). This leads to development of a system that incorporates these constructs in order to enhance learning. Learning style of students involves psychometric parameters, cognitive abilities and emotions; this describes the way students comprehend and react to the training environment (Keefe, 1979). Moreover, the way students opt for a learning environment puts an impact on their intellectual performance (Cassidy, 2004). This raises an interest in studying the relationship of students' learning behavior with academics (Debdi, Paredes-Velasco \& Velázquez-Iturbide, 2016). Further strategies for self-regulation and analysis of data retrieved from online educational environments can be used to predict intellectual performance of students (Pardo, Han \& Ellis, 2016).

The study in previous researches have shown that there exists a significant relationship between intellectual and non-intellectual constructs which raised the need of constructing model which can benefit improving the academic performance of students. The paper proposes models which aim at finding regression weights of student non-intellectual correlates which impact their academic scores. It was found that some parameters have positive weights whereas others have negative weights. The results obtained can be utilized to enhance the performance of the undergraduate students in academics.

Section 2 discusses about various non-intellectual constructs related to scholastic performance of students and describes the research framework. Research methodology is defined in section 3 . Validity and reliability of the model is discussed in section 4 . Section 5 describes the models, its results and findings; and finally, conclusion and future scope is defined in section 6.

\section{CONSTRUCTS AND RESEARCH FRAMEWORK}

The work proposes that psychometric parameters have an impact on academic learning of students. The non-academic constructs are operationalised in previous research (Richardson, Abraham \& Bond, 2012). Some constructs positively affect the academic performance whereas some have negative impact on it. Each construct is described along with its sub constructs and their relationship with grade of students is discussed. Based on these variables related hypotheses are then developed.

\section{Psychological Correlates Related to Grades of Student}

The relation between the non-intellectual correlates of student with their intellectual correlate can be used to enhance the academic performance (Burman, Som \& Hossain, 2018). The study considers six psychometric constructs namely - personality, motivation, self-regulatory learning strategies, students' approach towards learning, psychosocial contextual influences and demographics (Richardson et al., 2012). Few other factors are also considered involving extracurricular activities, high school background, social interaction network; and the facets stated in neo five factor model as shown in 
Table 2. The major factors are further divided into sub factors, as shown in Table 1, which can be used to describe the students' learning behavior in detail and analytical way.

\section{Personality Traits}

The dimensions (i.e., conscientiousness, openness, agreeableness, neuroticism, and extraversion) included in well-known five factor model represent the extensive and broadly enforced way of assessing personality of an individual (Costa \& McCrae, 1992). Conscientiousness is the measure which assesses an individual on the basis of being systematized or coordinated and their desire to succeed. Student having high conscientiousness performs well in academics and is determined in challenging subjects too (Mount \& Barrick 1995). Procrastination, the behavior to delay the work to the last minute, has a negative impact and is unrelated to intellectual correlate (Lay, 1986). Students who are highly procrastinated score low. Learners experiencing openness are imaginative, prefer variety and open to new ideas and innovations. They are capable of adopting new learning ideas in order to achieve high in academics. Agreeableness trait of personality is perceived as cooperative, sympathetic,

Table 1. Non-intellectual constructs related to academic performance of students

\begin{tabular}{|c|c|c|c|c|c|}
\hline Personality Traits & $\begin{array}{l}\text { Motivational } \\
\text { Factors }\end{array}$ & $\begin{array}{c}\text { Self-Regulatory } \\
\text { Learning } \\
\text { Strategies }\end{array}$ & $\begin{array}{l}\text { Approach Towards } \\
\text { Learning }\end{array}$ & $\begin{array}{c}\text { Psychosocial } \\
\text { Contextual Factors }\end{array}$ & Demographics \\
\hline Conscientiousness & Locus of control & Anxiety & Deep & Social integration & Gender \\
\hline Procrastination & Pessimistic & Rehearsal & Strategic & $\begin{array}{l}\text { Academic } \\
\text { integration }\end{array}$ & Age \\
\hline Openness & Optimistic & Organization & Surface & $\begin{array}{l}\text { Institutional } \\
\text { integration }\end{array}$ & Family background \\
\hline Neuroticism & Self-efficacy & Elaboration & & Goal commitment & $\begin{array}{l}\text { Socio economic } \\
\text { status }\end{array}$ \\
\hline Agreeableness & Self esteem & Critical thinking & & Social support & Disability \\
\hline Extraversion & Intrinsic motivation & Metacognition & & Stress & \\
\hline Need for cognition & $\begin{array}{l}\text { Extrinsic } \\
\text { motivation }\end{array}$ & Effort regulation & & & \\
\hline \multirow[t]{4}{*}{$\begin{array}{l}\text { Emotional } \\
\text { intelligence }\end{array}$} & Goal orientation & Help seeking & & & \\
\hline & & Peer learning & & & \\
\hline & & $\begin{array}{l}\text { Time/Study } \\
\text { management }\end{array}$ & & & \\
\hline & & Concentration & & & \\
\hline
\end{tabular}

Table 2. Parameters of neo five factor model

\begin{tabular}{|l|l|l|l|l|}
\hline Neuroticism & Extraversion & Openness & Agreeableness & Conscientiousness \\
\hline Anxiety & Warmth & Fantasy & Trust & Competence \\
\hline Hostility & Gregariousness & Aesthetics & Straight forwardness & Order \\
\hline Depression & Assertiveness & Feelings & Altruism & Dutifulness \\
\hline Self-consciousness & Activity & Actions & Compliance & Achievement striving \\
\hline Impulsiveness & Excitement seeking & Ideas & Modesty & Self-discipline \\
\hline Vulnerability to stress & Positive emotion & Values & Tender mindedness & Deliberation \\
\hline
\end{tabular}


kind, ready to accept others' views. Students with high agreeableness attend classes on regular basis, optimistic in behavior and show cooperation with their instructors resulting in enhanced learning (Vermetten, Lodewijks, \& Vermunt, 2001). Neuroticism is another correlate which is negatively related to academic performance. It leads to anxiety, stress (Steel, Brothen, \& Wambach, 2001) and reduce motivation (Watson, 2000) which affects learning in students. Students with high neuroticism have poor attendance and are found to be absent from examinations due to health issues (ChamorroPremuzic \& Furnham, 2002). Extrovert students are active socially and involve in activities. These students achieve less as they are distracted more towards social activities and involvement which reduce their learning time; limiting their effort towards intellectual tasks (Bidjerano \& Dai, 2007).

Other than factors of five factor model, construct need for cognition (Cacioppo, Petty \& Kao, 1984 ) is found to predict student academic performance. Higher need for cognition will lead to motivation in students and result in high performance. Altogether, seven personality measures have been identified that are associated with academic performance of students.

Other than the constructs explained in big five factor model, our study considered neo five factor model which reported six sub parameters of five personality traits termed as facets as discussed by Costa and McCrae shown in Table 1.

\section{Motivation Factors}

Various motivational theories exist (Eccles \& Wigfield, 2002) but only few constructs of motivation have been examined for predicting academic performance of students. Some students take their own responsibility for academic failure whereas others identify external causes such as course material, insufficient teaching. This is known as the locus of control (Rotter, 1966), a measure in which individuals consider that they have control over the consequences of acts in their lives. A pessimistic style (Peterson, Vaillant \& Seligman, 1988) is associated with negative outcome; defined as internal, unchanged and comprehensive attributions for past failures. Students presume that they are incapable of performing well. In contrast, optimistic students presume that they are well capable, do well in exams and the reason for their past failure may be non-understanding of the examiner. Learning skills and abilities enhance academic performance. Students who are self-efficient perform better than those with lower efficacy expectations (Bandura, 1997). Students may feel that their effort leads to success however they lack the required skills to mobilize such effort; hence the distinction is essential between the two.

Self-determination theory differentiated sources of motivation (Ryan \& Deci, 2000). The theory proposes that engagement in a task leads to gratification of psychological needs, namely, competent, relatedness and autonomy. Engaging in a task for personal reward, intrinsic motivation, will lead to optimal learning whereas tasks undertaken for external rewards, extrinsic motivation, may squelch academic achievement. Goal theories propose that setting up and aiming of a goal is related to achievement feedback. Achievement of a student consists of their past results of exams and assignments (Wood \& Locke, 1987). The goal a student undergoes during academic tenure serves as a degree of their achievement and motivation. Goal oriented and a self-efficient student performs well and the combination of the two is one of the powerful predictors of grades of learners (Pajares \& Miller, 1995).

\section{Self-Regulatory Learning Strategies}

As stated in "rubicon" model (Gollwitzer, 1990) the decision about the need to act and where to put efforts are elements of goal setting mechanism that anticipates goal committal. Achieving the set goal can be accomplished with regulation of emotions, cognitions, and environment and motivation behaviors by students. In this aspect, regulatory constructs aim to know how to implement efforts in best possible manner (Boekaerts \& Corno, 2005). The differences in adoption of self-regulatory strategies by students contribute to goal achievement more or less effective rendering predicting performance. This implies that evaluation of self-regulatory learning strategies aid greater veracity in envisioning intellectual performance. Cognitive strategies include rehearsal, elaboration, critical 
thinking and other generic constructs of self-regulation (Pintrich, 2004). The strategies, rehearsal referring repeating the learning, elaboration referring to summarizing the content in self words and critical thinking referring to assessment of facts to form conclusion; reflect in depth learning strategy which facilitate learning and attainment. Metacognition, part of self-regulatory learning strategies, construe higher order reasoning competencies appropriate for learning (Wolters, Pintrich $\&$ Karabenick, 2003). The construct anxiety is related to neuroticism affecting skeptically the learning behavior of students.

Behavioral constructs related to self-regulatory abilities (Pintrich, 2004) includes effort regulation that circumscribe individuals' management of endurance in case of challenging tasks, peer learning related to conversing with rivals about their learning, whereas time/study management involves evaluation of the usage of strategies made for study. Help seeking is also identified as behavioral strategy (Pintrich, 2000) including other regulation as such actions of instructors and peers. Concentration is another feature, included in the learning and study strategy inventory (LASSI) (Weinstein, Palmer \& Schulte, 1987), evaluate the ability of learners to focus during study.

\section{Psychosocial Contextual Factors}

The retention of students is also impacted by the institution itself (Tinto, 1982). It has been noted that students with substantial institution and academic integration leads to optimal results. Some additional constructs, as such support by family members and finances, also direct the responses of students in university life involving responses of stress and depression, affecting integration and academic performance.

\section{Students' Approach Towards Learning}

Approaches towards learning can be categorized into three (Biggs, 1987). The deep learning approach refers to the learning style including critical thinking and exploring the concepts with desire to learn. In contrast, the surface approach is comprised of shallow learning with extrinsic motivation to learn. Students may also follow the strategic approach in place of the above stated which involves both styles of learning deep and surface on the basis of the importance and characteristics of the task.

\section{Demographic Feature}

The diversity in population results in the need of exploring the consequence of demographic on academic performance. It has been seen that students belonging to higher socioeconomic backgrounds score high as compared to their counterparts (Dennis, Phinney, \& Chuateco, 2005). Literature shows that gender, age, family background and disability is also considered in predicting academic performance other than socio economic background (Shahiri \& Husain, 2015).

Few other parameters are also considered, apart from those discussed above, influencing academic performance includes extracurricular activities, high school background, social interaction network and emotional skills (Mishra, Kumar, \& Gupta, 2014; Angeline, 2013; Elakia \& Aarthi, 2014).

The information retrieved from previous work raises two questions- a) are all non-intellectual constructs essential to the study? and b) is it possible to have a model based on these constructs which can provide insight to enhance the performance of students?

\section{Research Hypotheses}

Evidences have shown that educational institutes can enhance their results by analyzing the nonintellectual parameters of students in addition to intellectual constructs. Non-intellectual constructs directly impact the academic performance (Richardson et al., 2012) and institutes should use them to excel. Richardson et al. (2012) uses two stage structural equation modeling (TSSEM) for examining a regression model based on non-intellectual correlates. They found three combinations of personality constructs i.e. models are created for procrastination with conscientiousness, need for cognition with conscientiousness and emotional intelligence with conscientiousness. In (Poropat, 2009) it was found 
that student academic performance can be predicted by conscientiousness. This arise the need to test the significance of personality traits on academic performance of students.

Hypotheses 1: Personality traits affect the academic performance of students.

Also, in (Richardson et al., 2012) a model with three constructs of motivational constructs is established, locus of control, academic self-efficacy and grade goal. The study by (Pajares \& Miller, 1995) found that self-efficacy and grade goal are the strong predictors for academic performance.

Hypotheses 2: Higher levels of motivation lead to higher performance.

It was stated that evaluation of learning strategies aid greater accuracy for performance prediction by (Wolters et. al., 2003). Effort regulation is one of the predictors of academic performance as concluded by (Robbins, Lauver, Le, Davis, Langley, \& Carlstrom, 2004). A regression model with learning strategies constructs including elaboration, critical thinking, meta cognition, effort regulation, help seeking and time/study management is given by (Richardson et al., 2012) for predicting academic performance of students.

Hypotheses 3: Regulating the learning strategies will results in better scores.

The study by (Tinto, 1975) demonstrates that the way an institute demonstrates itself consequent the disengagement of its own students. It considers various characteristics of students like gender, values, past experiences to discover the student engagement with their peers, mentors and university system. This will help in knowing their integration with academic and social. It was found that positive engagement with social and academic results in goal commitment and those having conflicts are not able to perform well. The study of other factors like support by family, financial assistance influence integration and direct the responses of students on stress and discouragement to university life (Levin \& Rubin, 1998).

Hypotheses 4: Psychosocial contextual factors have an impact on learning

Diverse population in the university raises the need to study about influence of demographic feature on academic achievement of students. The study by (Robbins et al., 2004) showed that students with higher socioeconomic background tend to score high than their counterparts.

Hypotheses 5: Demographic feature influences academic achievement

The work carried in (Pintrich, 2004) discusses about influence of different learning approaches adopted by students on their academic performance. The study by (Biggs, 1987) identified three broad learning approaches - deep learning, strategic learning and surface learning.

Hypotheses 6: Learning approaches have an impact on academic performance

The constructs affecting the academic performance are identified from different studies during the extensive literature and the collective effect of the entire construct on performance is addressed in present study. For personality, the models construct comprising conscientiousness, procrastination, need for cognition and emotional intelligence (Richardson et al., 2012; Poropat, 2009) is included. 
The constructs like locus of control, self-efficacy and grade goal (Pajares \& Miller, 1995) is tested for motivation. As per SRLS, elaboration, critical thinking, meta cognition, help seeking, effort regulation and time/study management are also taken under account (Wolters et al., 2003; Richardson et al., 2012; Robbins et al., 2004). Also, the review showed that no model exist for psychosocial contextual influences and demographic feature and hence not tested. Current study considers all these as inputs to study the impact on student learning.

\section{Research Methodology}

Figure 1 describes the research methodology followed. This section describes the process of development of instrument, data collection and analysis. The instrument development is comprised of generations of items, their pre-pilot and pilot study.

Figure 1. Research methodology

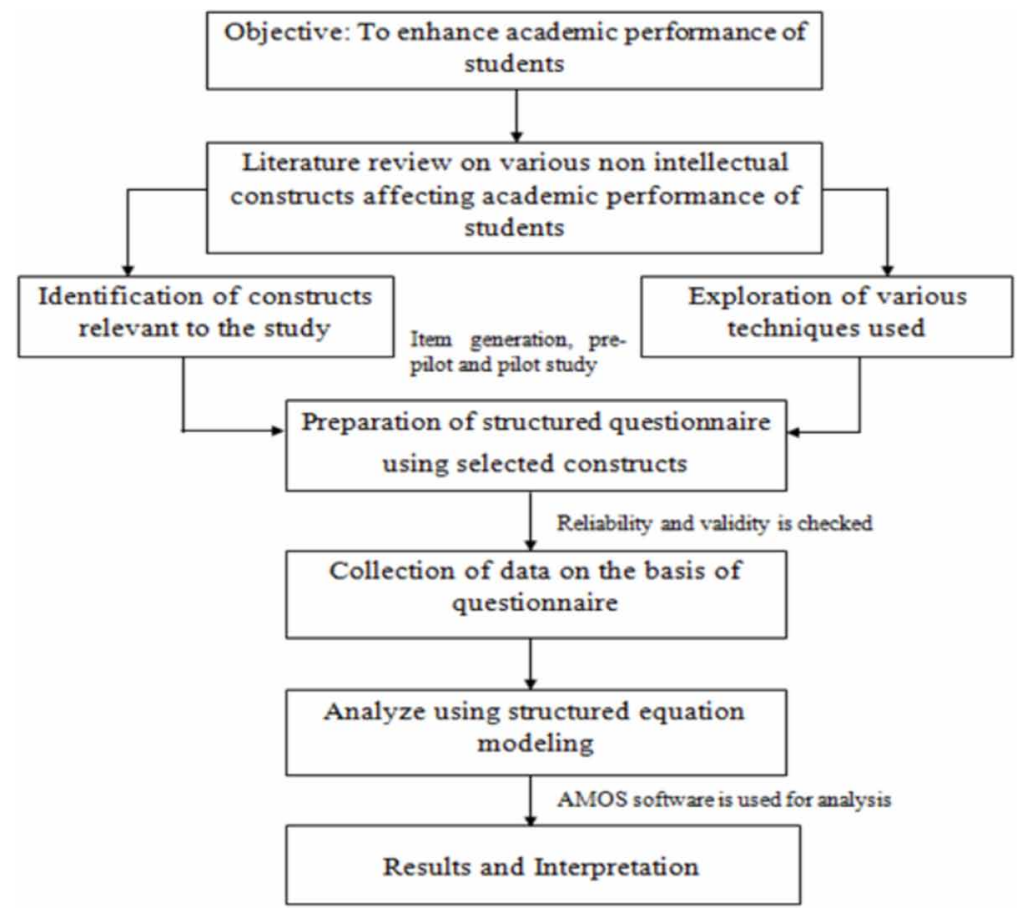

\section{Generating Items, Pre-Pilot and Pilot Study}

It is important to cover the domain of the constructs so that the validity can be improved as stated in (Churchill, 1979). Hence, the study considers the statements covering all the items discussed in the literature and the definitions of the constructs which has not been covered yet to answer the questions stated in section 2. In pre-pilot study the items were reviewed by one psychology expert and a doctoral student. Sample data from a hundred students is collected on those statements and pilot study is done. The factor analysis is performed on the statements and it was found that few statements were not significant arose the need to drop those statements. Finally, the significant statements were taken into consideration for preparation of the structured questionnaire to collect the data for analysis. It is comprised of questions related to the psychological behavior of students. 


\section{Data Collection}

The study focuses on enhancement of academic performance of tertiary students; hence, the target respondents were undergraduate students (of final year). In order to select the respondents' probability sampling is used. First, a list of universities affiliated colleges is prepared running distinct courses. Out of those 11 are selected at random. Students from these colleges are selected randomly for data collection. The responses are recorded on the scale of 1 to 5 (from strongly agree to strongly disagree) by the interviewer. The learning approach feature is recorded in the form of categorical data. Large number of observations, 2,198, are collected from the students out of which 187 are found to be biased in nature. These observations were dropped and the final sample size is of 2,011 which is statistically justified according to the nature of study (Levin \& Rubin, 1994). The study is extensive in nature as the observations of students studying heterogeneous courses are taken under the study.

\section{Analysis}

The structured equation modeling (SEM) is performed using AMOS software on the dataset to obtain the models. Although various techniques are available for analytics. But the complexity of the model under present study can be well examined using SEM as the study is having dependent, independent and the latent variables. SEM is an efficient tool to deal with these complexities (Karimi \& Meyer, 2014). It is a powerful tool for identifying relationships and to uncover their strength and causal nature (Bollen, 1989; Bollen \& Long, 1993). This makes it useful in dealing with complex problems in various fields. In e-learning it has been used to enumerate critical success factors anticipated by students (Selim, 2007). Another use of SEM is seen in (Lee \& Choi, 2013), to enhance the student retention based on learning strategies, flow experience, internal academic locus of control (ALOC), and student satisfaction. Also, to study the impact of supply chain responsiveness on a firm's competitive advantage SEM is used and it produces decisive results in this convoluted study (Thatte, Rao \& Ragu-Nathan, 2013). SEM has developed and improved over the period of time. Early in 1900s it was used for path analysis, factor analysis, reliability, regression; later it was used for nonlinear problems, formative models, bootstrapping; and currently SEM development includes partial least square (PLS), multilevel-mixture models, SEM-based meta-analysis and generalized linear latent and mixed modelling (GLLAMM) (Karimi \& Meyer, 2014). Further, the effect of non-academic correlates on student academic performance is examined by (Richardson et al., 2012) using SEM. The present study is enhanced version of the Indian scenario. The results of the models showed that changing the psychometric parameters of student can lead to improvement in their grades. For learning approach construct logistic regression is applied to study the effect of different learning approaches on student academic performance.

\section{Measurement Model}

It is important to test the model for validity and reliability of constructs. The discriminant validity, convergent validity and reliability are essential for the validity of constructs. For construct validity structured equation modeling (SEM) is used. "In recent years SEM has gain insight in analyzing psychology data. The current study deals with psychometric factors of students related to their academic performance. The data has been analyzed using regression model also, but the results were found not fit. SEM provides us with beta coefficient that gives the estimated contribution of a specific construct. Also, the relation of construct with academic performance is known. In order to check the internal consistency of operationalization reliability check is implemented.

\section{Construct Validity}

Construct validity comprise of convergent validity and discriminant validity. An essential step in testing the model is the evaluation of instrument. Confirmatory factor analysis (CFA) is performed using AMOS software and then SEM is applied to test the relationship of hypothesis. Multiple fit 
indices are evaluated to fit the model data. The fit indices include goodness of fit (GFI), adjusted goodness of fit (AGFI) and root mean square (RMSEA). The values ranging from 0.8 to 0.9 is considered as acceptable fit for GFI and AGFI (Joreskog \& Sorbom, 1989) and a value between 0.05 and 0.08 is acceptable for RMSEA (Browne, Cudeck, Bollen, \& Long, 1993). If the fit indices of the model are not acceptable then the modification in the model is carried out on the basis of the values of modification indices (MI). Multicollinearity, refers to high item correlations among independent variables, is represented by MI i.e. explaining commonality. The final model with fit indices is then constructed. Table 3 shows the model fit indices for the constructs.

The independence of constructs measuring single parameter is referred to as discriminant validity. SEM methodology is used to assess discriminant validity. It was found that very low correlation exists among the constructs illustrating high degree of discriminant validity.

\section{Reliability}

In order to check the reliability of the constructs Cronbach alpha value is computed. The accepted value of alpha for internal consistency of operationalization is 0.7 (Hair, Anderson, Tatham, \& William, 1998). It was found that reliabilities of the constructs vary from 0.8 to 0.89 , which is above the accepted value.

\section{RESULTS AND INTERPRETATION}

Different models have been tested to examine the hypothesized relationship of each non-intellectual correlate with academic performance of students. The beta coefficients of each construct and variance explained by model are given in Table 4 .

\section{Personality Factors}

The relationship among personality constructs and grades, as stated in Hypotheses 1 , is tested. It is found that seven constructs are significant out of which conscientiousness $(\beta=0.592)$ is the strongest construct to predict the academic performance of students. Procrastination provides least contribution which is less than $1 \%$ approximately null $(\beta=0.081)$ and extraversion $(\beta=0.286)$ also positively affected the performance. On the other hand, openness $(\beta=-0.176)$, agreeableness $(\beta=-0.262)$, neuroticism $(\beta=-0.085)$ and need for cognition $(\beta=-0.116)$ negatively affect the performance of students. The model depicted in Figure 2, explains $26.2 \%$ of variance with grades of students.

\section{Motivational Factors}

This model includes six constructs (locus of control, intrinsic motivation, extrinsic motivation, optimistic, self-efficacy and goal orientation). It explains $1 \%$ of variance with grades of students with positive beta coefficients for intrinsic motivation $(\beta=0.431)$, optimistic $(\beta=0.569)$, self-efficacy $(\beta$ $=0.057)$ and negative beta coefficients for locus of control $(\beta=-0.211)$, extrinsic motivation $(\beta=$ -0.391), goal orientation $(\beta=-0.308)$.

\section{Self-Regulatory Learning Strategies}

Seven out of ten constructs significantly affect the academic performance of students. Only two of the significant constructs report negative values which are metacognition $(\beta=-0.3 .630)$ and time/study management $(\beta=-0.561)$. Others report positive beta coefficients as for anxiety $(\beta=0.970)$, rehearsal ( $\beta=0.495)$, critical thinking $(\beta=1.704)$, effort regulation $(\beta=1.984)$ and peer learning $(\beta-0.501)$. This model accounted for $17 \%$ of variance. 
Table 3. Model fit indices

\begin{tabular}{|c|c|c|}
\hline Items & Initial Model Fit & Final Model Fit \\
\hline \multicolumn{2}{|l|}{ Personality factors } & \\
\hline \multicolumn{3}{|l|}{ Conscientiousness } \\
\hline \multicolumn{3}{|l|}{ Procrastination } \\
\hline Openness & $\mathrm{GFI}=0.804$ & $\mathrm{GFI}=0.933$ \\
\hline Neuroticism & $\mathrm{AGFI}=0.735$ & $\mathrm{AGFI}=0.888$ \\
\hline Agreeableness & RMSEA $=0.114$ & RMSEA $=0.069$ \\
\hline \multicolumn{3}{|l|}{ Extraversion } \\
\hline \multicolumn{3}{|l|}{ Need for cognition } \\
\hline \multicolumn{3}{|l|}{ Emotional intelligence } \\
\hline \multicolumn{3}{|l|}{ Motivational factors } \\
\hline \multicolumn{3}{|l|}{ Locus of control } \\
\hline \multicolumn{3}{|l|}{ Pessimistic } \\
\hline Optimistic & $\mathrm{GFI}=0.753$ & $\mathrm{GFI}=0.916$ \\
\hline Self-efficacy & AGFI $=0.665$ & $\mathrm{AGFI}=0.870$ \\
\hline Self esteem & $\mathrm{RMSEA}=0.131$ & RMSEA $=0.082$ \\
\hline \multicolumn{3}{|l|}{ Intrinsic motivation } \\
\hline \multicolumn{3}{|l|}{ Extrinsic motivation } \\
\hline \multicolumn{3}{|l|}{ Goal orientation } \\
\hline \multicolumn{3}{|c|}{ Self-regulatory learning strategies } \\
\hline \multicolumn{3}{|l|}{ Anxiety } \\
\hline \multicolumn{3}{|l|}{ Rehearsal } \\
\hline \multicolumn{3}{|l|}{ Organization } \\
\hline \multicolumn{3}{|l|}{ Elaboration } \\
\hline Critical thinking & $\mathrm{GFI}=0.537$ & $\mathrm{GFI}=0.889$ \\
\hline Metacognition & AGFI $=0.422$ & $\mathrm{AGFI}=0.824$ \\
\hline Effort regulation & RMSEA $=0.155$ & RMSEA $=0.082$ \\
\hline \multicolumn{3}{|l|}{ Help seeking } \\
\hline \multicolumn{3}{|l|}{ Peer learning } \\
\hline \multicolumn{3}{|l|}{ Time/Study management } \\
\hline \multicolumn{3}{|l|}{ Concentration } \\
\hline \multicolumn{3}{|c|}{ Psychosocial contextual influences } \\
\hline Social integration & $\mathrm{GFI}=0.928$ & $\mathrm{GFI}=0.985$ \\
\hline Academic integration & AGFI $=0.871$ & $\mathrm{AGFI}=0.969$ \\
\hline \multirow[t]{2}{*}{ Stress } & RMSEA $=0.112$ & RMSEA $=0.035$ \\
\hline & Demographic feature & \\
\hline Upper socioeconomic status & $\mathrm{GFI}=0.882$ & $\mathrm{GFI}=0.928$ \\
\hline Middle socioeconomic status & AGFI $=0.825$ & $\mathrm{AGFI}=0.915$ \\
\hline Lower socioeconomic status & RMSEA $=0.06$ & RMSEA $=0.045$ \\
\hline
\end{tabular}


Figure 2. Model for personality traits

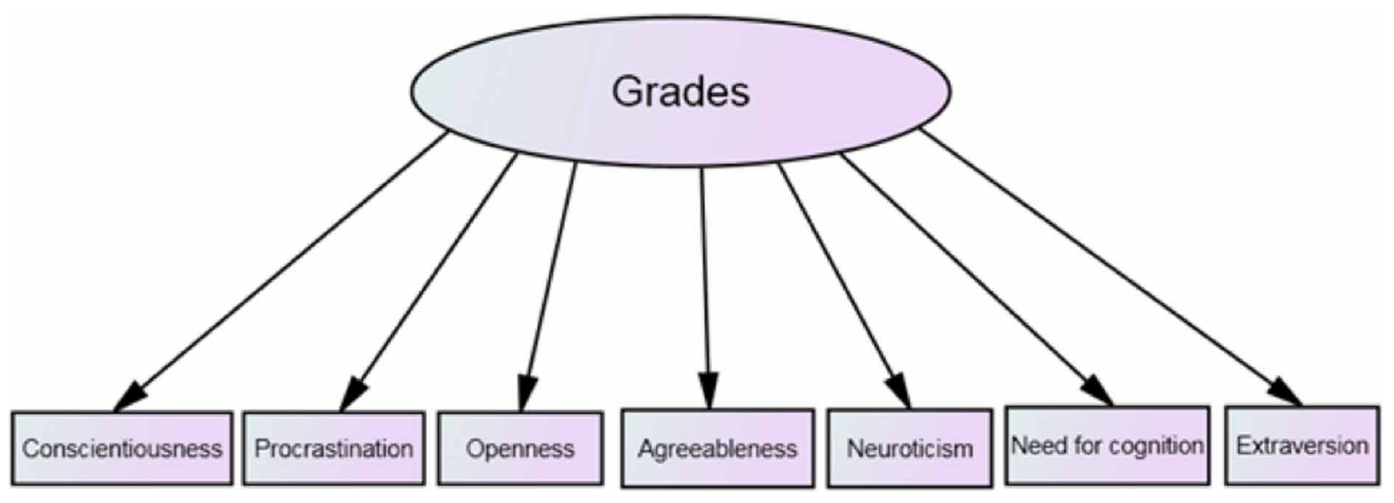

Figure 3. Model for motivational factors

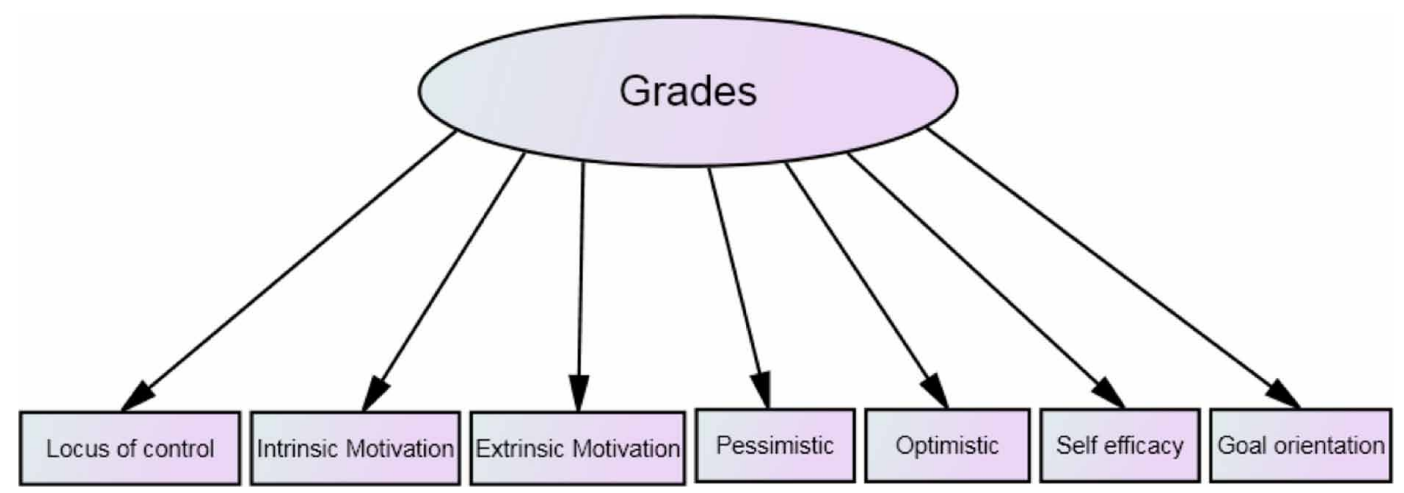

Figure 4. Model for self-regulatory learning strategies

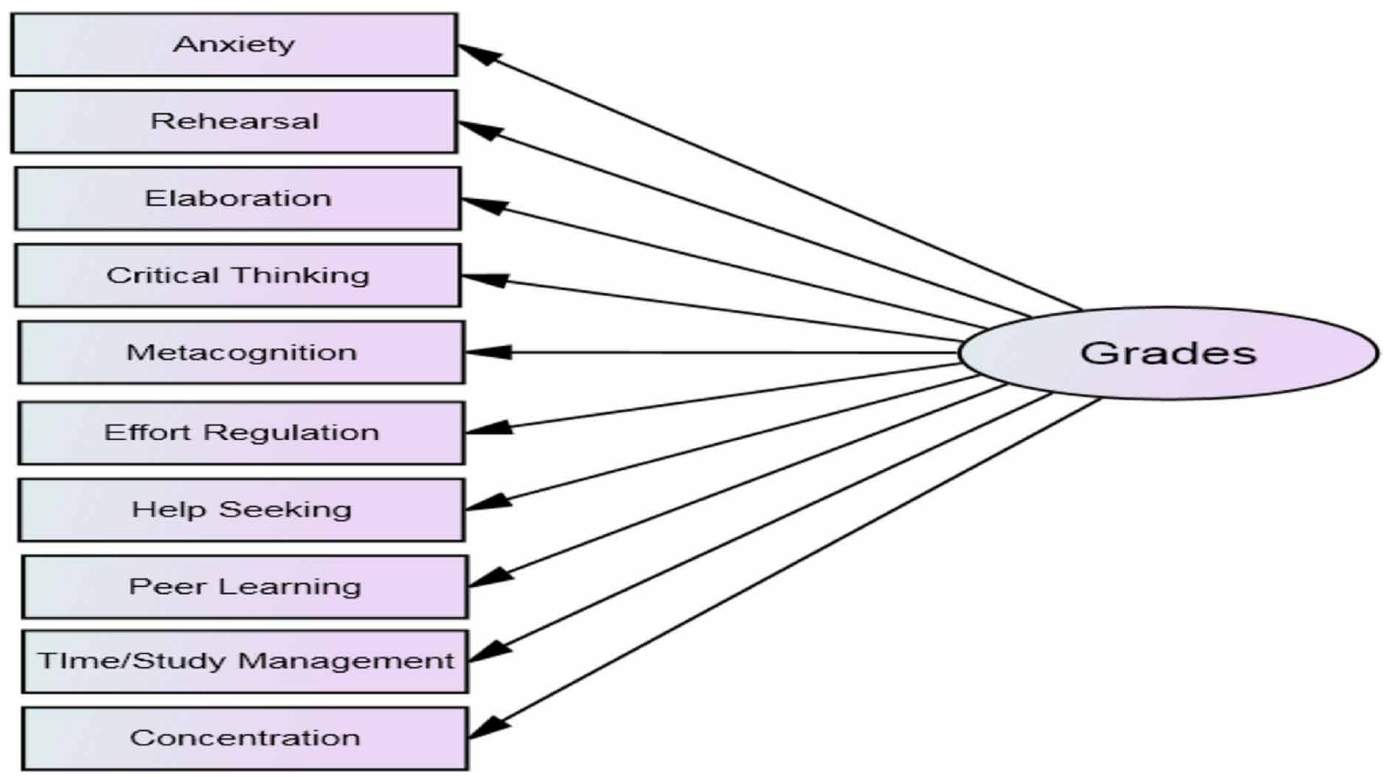


Figure 5. Model for psychosocial contextual factors

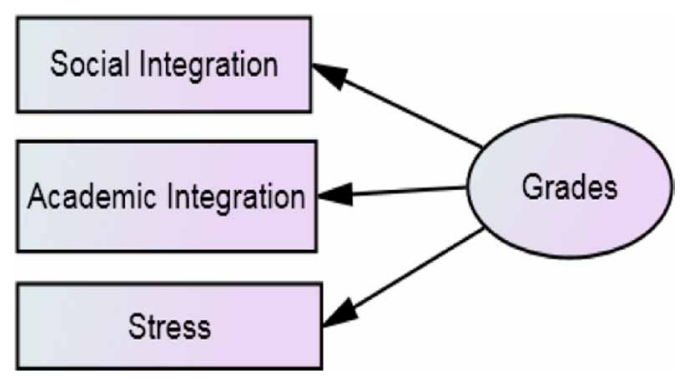

\section{Psychosocial Contextual Factors}

All the three constructs are found significant. Academic integration is found negatively related with $\beta=-0.520$; and social integration and stress are found positively related with $\beta=0.0716$ and $\beta=$ 0.057 respectively. The model explains $4.6 \%$ of variance with grades of students.

\section{Student Approach Towards Learning}

Logistic regression is used to obtain the results in order to study the relationship of learning approach with grades of students. The beta coefficients are as, for deep learning $(\beta=0.823)$, for strategic learning $(\beta=0.648)$ and for surface learning $(\beta=0.353)$.

\section{Demographic Feature}

It checked the socioeconomic status of the learners. The constructs are found significant with positive beta coefficients for upper socioeconomic status, middle socioeconomic status and lower socioeconomic status ranging between 1.4 and 1.8. This model accounted for $4.9 \%$ of variance.

\section{CONCLUSION AND IMPLICATIONS OF RESEARCH}

The study highlights various non-intellectual parameters essential for enhancing academic performance of undergraduate students. It aims for finding the constructs which lead to success and those which deviate students from their marks. The models help us to identify the constructs which lead to enhancement in academic achievement of students. Table 5 describes various key findings related to research. It discusses about the significance of constructs on learning of student. This majorly contributes in enhancing intellectual performance of students which inherently improvise employability, retention of students in class and benefit institute, student and society in large.

Figure 6. Model for demographic feature

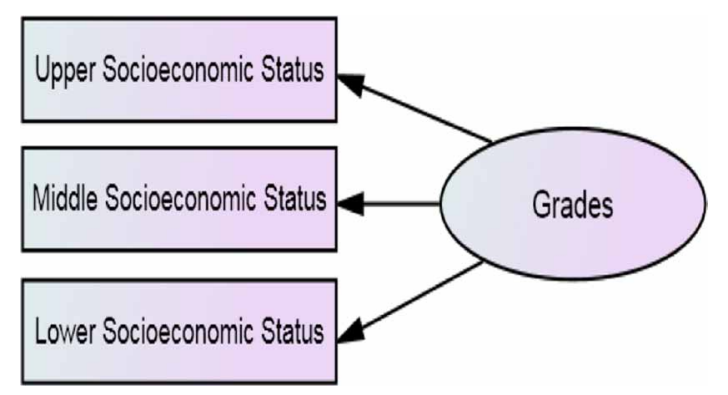


Table 4. Different models for academic performance

\begin{tabular}{|l|l|l|l|l|l|l|}
\hline & \multicolumn{1}{|c|}{ Personality } & \multicolumn{1}{|c|}{ Motivation } & \multicolumn{1}{|c|}{ SRLS } & \multicolumn{1}{c|}{ PCF } & \multicolumn{1}{c|}{ Demographic } & \multicolumn{1}{c|}{ LA } \\
\cline { 2 - 7 } & $\begin{array}{c}\text { C, P, O, A, E, } \\
\text { NFC, N }\end{array}$ & $\begin{array}{c}\text { LOC, IM, EM, } \\
\text { OP, SE, GO }\end{array}$ & $\begin{array}{c}\text { Anxiety, R, } \\
\text { CT, MC, ER, } \\
\text { PL, TSM }\end{array}$ & SI, AI, Stress & $\begin{array}{c}\text { Upper, Middle, } \\
\text { Lower }\end{array}$ & $\begin{array}{c}\text { Deep, Surface, } \\
\text { Strategic }\end{array}$ \\
\hline$\beta$ & $0.592^{* * *}$ & $-0.211^{* *}$ & $0.970^{* * *}$ & $0.0716^{* * *}$ & $1.480^{* * *}$ & 0.823 \\
\hline$\beta$ & $0.081^{*}$ & $0.431^{* * *}$ & $0.495^{* *}$ & $-0.520^{* * *}$ & $1.726^{* * *}$ & 0.648 \\
\hline$\beta$ & $-0.176^{* *}$ & $-0.391^{* *}$ & $1.704^{* * *}$ & $0.057^{* *}$ & $1.543^{* * *}$ & 0.353 \\
\hline$\beta$ & $-0.262^{* * *}$ & $0.569^{* * *}$ & $-3.630^{* * *}$ & - & - & - \\
\hline$\beta$ & $0.286^{* * *}$ & $0.057^{*}$ & $1.984^{* * *}$ & - & - & - \\
\hline$\beta$ & $-0.116^{* *}$ & $-0.308^{* * *}$ & $0.501^{* *}$ & - & - & - \\
\hline $\mathrm{R}^{2}$ & $-0.085^{*}$ & - & $-0.561^{* *}$ & - & - & - \\
\hline $\mathrm{C}$ & 0.262 & 0.010 & 0.170 & 0.046 & 0.049 & - \\
\hline
\end{tabular}

C-conscientiousness; P-procrastination; O-openness; A-agreeableness; E-extraversion; NFC-need for cognition; N-neuroticism; LOC-locus of control; IM-intrinsic motivation; EM-extrinsic motivation; OP-optimistic; SE-self efficacy; GO-goal orientation; R-rehearsal; CT-critical thinking; MC-meta cognition; ER-effort regulation; PL-peer learning; TSM-time/study management; SI-social integration; Al-academic integration.

${ }^{* * *} p<.001 ;{ }^{* *} p<.05 ;{ }^{*} p<.10$

The study has various implications for analysts. Firstly, it is found that personality traits of a student contribute majorly in academic performance. It is seen that students with high degree of conscientiousness may score high marks in comparison to their counterparts. Procrastination defining the delaying behavior depicting delaying the work to the last-minute deviates the student from scoring well. Extraversion i.e. assertive, positive behavior will help in improving performance. Neuroticism, when a student experiences depression, worry about their academic outcomes may lead to lower grades. It is seen that cognitive abilities; defining thinking skills, understanding, memory-based learning; are low in our students. Hence in order to enhance their performance effort is required to improve their cognition. Also, openness and agreeableness lead to lower grades.

Second, for motivational factors it is concluded that students who are self-motivated tend to score high than extrinsically motivated students. Also, students with positive attitude towards their efforts and having confidence on their academic capabilities perform well in academics. Third, as per strategies followed for learning it has been noted that students practicing the contents studied, putting their best efforts towards learning, tries to discuss with peers in order to learn more, and anxious for their future tend to perform well in academics as compared to their counterparts. Critical thinking referring to analytical skills to conclude judgments lead to success. Fourth, it is seen that the deep and strategic approaches towards learning help students in enhancing their academic performance as compared to surface approach followed for passing the examination.

Fifth, for psychosocial contextual factors, it is found that social integration like family support, financial assistance, and interaction with peers will help students to score high marks. Also, students who are concern about their future, take stress for it perform well. Although socio economic status is found significant but the difference in socio economic status of students does not provide much difference in their academic performance.

Sixth, education sector in India is getting weak. As per the report by Aser Center, a survey on level of education of youth in India, it is found that $40 \%$ of students are unable to do basic calculation and to read a simple English sentence. Young generation is future of our country which makes this a major societal problem. Further, this results in decreased job rate. By enhancing the academic performance of students this problem can be fully removed and it benefits our education sector. Moreover, this increases employability as education sector is linked to the industry. 
Table 5. Summary and key findings

\begin{tabular}{|l|l|}
\hline \multicolumn{1}{|c|}{ Construct } & \multicolumn{1}{c|}{ Key Findings } \\
\hline Personality & $\begin{array}{l}\text { Personality constructs puts a positive impact on students' performance. It makes them } \\
\text { organized, open to accept new problems and to follow innovative ways to solve them, bring } \\
\text { punctuality and build seriousness. }\end{array}$ \\
\hline Motivation & $\begin{array}{l}\text { These constructs help students in locus of control, motivate them, build positive attitude, } \\
\text { makes them self-efficient and goal oriented. Including these in addition to their curriculum will } \\
\text { significantly help in improving their development. }\end{array}$ \\
\hline $\begin{array}{l}\text { Self-regulation } \\
\text { strategies for learning }\end{array}$ & $\begin{array}{l}\text { It encourages students to strengthen their cognitive skills and abilities, manage time, practice } \\
\text { the subject matter, and regulate their efforts. }\end{array}$ \\
\hline $\begin{array}{l}\text { Psychosocial } \\
\text { contextual influences }\end{array}$ & $\begin{array}{l}\text { Integration of students socially and academically helps students in acquiring knowledge from } \\
\text { peers and instructors. This is beneficial especially in the case when student is unable to attend } \\
\text { the class due to medical reason. }\end{array}$ \\
\hline $\begin{array}{l}\text { Approach towards } \\
\text { learning }\end{array}$ & $\begin{array}{l}\text { Knowing the subject matter with deep concepts and background details assist the students in } \\
\text { learning in an effective way. }\end{array}$ \\
\hline Demographic & $\begin{array}{l}\text { The impact of this construct on the learning of students is found almost equal for each of its sub } \\
\text { construct. }\end{array}$ \\
\hline
\end{tabular}

\section{LIMITATIONS AND FUTURE SCOPE}

Though this study contributes significantly from empirical and theoretical view, certain other aspects are required to be incorporated to enhance maximum benefits from it.

Foremost, the research is limited to students of metropolitan cities and data of rural and remote areas is not included. Although data under study covers different colleges but the probability of a student not belonging to non-metropolitan city is rare. Hence no opinion can be given on model fit in other areas. The study therefore can be extended to include students nationwide.

Second, this study has considered the present behavior and patterns as depicted by the students. Other key parameters such as genetic impact, environmental effects on the student's learning and upbringing, education level of parents, type of learning skills etc. can be further included to strengthen the outcome of this study. These features might influence learners' perception.

This research can be further extended in developing a recommender system for the students to improve their learning behavior at the earliest deviation thereby helping them to enhance their performance. 


\section{REFERENCES}

Ackerman, P. L., \& Heggestad, E. D. (1997). Intelligence, personality, and interests: Evidence for overlapping traits. Psychological Bulletin, 121(2), 219-245. doi:10.1037/0033-2909.121.2.219 PMID:9100487

Anderson Koenig, J. (2011). Assessing 21st century skills: Summary of a workshop. Washington, DC: The National Academic Press.

Angeline, D. M. D. (2013). Association rule generation for student performance analysis using Apriori algorithm. The SIJ Transactions on Computer Science Engineering \& its Applications (CSEA), 1(1), 12-16.

Bandura, A. (1997). Self-efficacy: The exercise of control. New York, NY: Freeman.

Bidjerano, T., \& Dai, D. Y. (2007). The relationship between the Big-Five model of personality and self-regulated learning strategies. Learning and Individual Differences, 17(1), 69-81. doi:10.1016/j.lindif.2007.02.001

Biggs, J. B. (1987). The Learning Process Questionnaire (LPQ): Manual. Hawthorn, Victoria, Australia: Australian Council for Educational Research.

Blackwell, L. S., Trzesniewski, K. H., \& Dweck, C. S. (2007). Implicit theories of intelligence predict achievement across an adolescent transition: A longitudinal study and an intervention. Child Development, 78(1), $246-263$. doi:10.1111/j.1467-8624.2007.00995.x PMID:17328703

Boekaerts, M., \& Corno, L. (2005). Self-regulation in the classroom: A perspective on assessment and intervention. Applied Psychology, 54(2), 199-231. doi:10.1111/j.1464-0597.2005.00205.x

Bollen, K. A. (1989). Structural equations with latent variables. New York, NY: John Wiley \& Sons. doi:10.1002/9781118619179

Bollen, K. A., \& Long, J. S. (1993). Structural equations with latent variables. New York: John Wiley \& Sons.

Browne, M. W., Cudeck, R., Bollen, K. A., \& Long, J. S. (1993). Testing structural equation models.

Burman, I., Som, S., Hossain, S.A. (2018). Meta-analysis of psychometric measures and prediction of student's learning behaviour using regression analysis and svm. Journal of Advanced Research in Dynamical and Control Systems.

Butler, D. L., Beckingham, B., \& Lauscher, H. J. N. (2005). Promoting strategic learning by eighth-grade students struggling in mathematics: A report of three case studies. Learning Disabilities Research \& Practice, 20(3), 156-174. doi:10.1111/j.1540-5826.2005.00130.x

Byrnes, J. P. (2003). Factors predictive of mathematics achievement in White, Black, and Hispanic 12th graders. Journal of Educational Psychology, 95(2), 316-326. doi:10.1037/0022-0663.95.2.316

Cacioppo, J. T., Petty, R. E., \& Kao, C. F. (1984). The efficient assessment of need for cognition. Journal of Personality Assessment, 48(3), 306-307. doi:10.1207/s15327752jpa4803_13 PMID:16367530

Cassidy, S. (2004). Learning styles: An overview of theories, models, and measures. Educational psychology, 24(4), 419-444.

Chamorro-Premuzic, T., \& Furnham, A. (2002). Neuroticism and "special treatment" in examinations. Social Behavior and Personality, 30(8), 807-811. doi:10.2224/sbp.2002.30.8.807

Chamorro-Premuzic, T., \& Furnham, A. (2008). Personality, intelligence and approaches to learning as predictors of academic examination performance. Personality and Individual Differences, 44(7), 1596-1603. doi:10.1016/j. paid.2008.01.003

Churchill, G. A. Jr. (1979). A paradigm for developing better measures of marketing constructs. JMR, Journal of Marketing Research, 16(1), 64-73. doi:10.1177/002224377901600110

Cleary, T. J., Gubi, A., \& Prescott, M. V. (2010). Motivation and self-regulation assessments in urban and suburban schools: Professional practices and needs of school psychologists. Psychology in the Schools, 47(10), 985-1002. doi:10.1002/pits.20519 
Costa, P. T. Jr, \& McCrae, R. R. (1992). Four ways five factors are basic. Personality and Individual Differences, 13(6), 653-665. doi:10.1016/0191-8869(92)90236-I

Debdi, O., Paredes-Velasco, M., \& Velázquez-Iturbide, J. Á. (2016). Influence of pedagogic approaches and learning styles on motivation and educational efficiency of Computer Science students. IEEE Revista Iberoamericana de Tecnologias del Aprendizaje, 11(3), 213-218. doi:10.1109/RITA.2016.2590638

Dennis, J. M., Phinney, J. S., \& Chuateco, L. I. (2005). The role of motivation, parental support, and peer support in the academic success of ethnic minority first-generation college students. Journal of College Student Development, 46(3), 223-236. doi:10.1353/csd.2005.0023

Dignath, C., \& Büettner, G. (2008). Components of fostering self-regulated learning among students. A metaanalysis on intervention studies at primary and secondary school level. Metacognition and Learning, 3(3), 231-264. doi:10.1007/s11409-008-9029-x

Eccles, J. S., \& Wigfield, A. (2002). Motivational beliefs, values, and goals. Annual Review of Psychology, 53(1), 109-132. doi:10.1146/annurev.psych.53.100901.135153 PMID:11752481

Elakia G., Aarthi N. J. (2014). Application of data mining in educational database for predicting behavioural patterns of the students. International Journal of Computer Science and Information Technologies, 4649-4652.

Gollwitzer, P. (1990). Action phases and mind-sets. In E. T. Higgins \& R. M. Sorrentino (Eds.), Handbook of motivation and cognition (Vol. 2, pp. 53-92). New York, NY: Guilford Press.

Grolnick, W. S., \& Raftery-Helmer, J. N. (2015). Contexts supporting self-regulated learning at school transitions. In T. J. Cleary (Ed.), Self-regulated learning interventions: Enhancing adaptability, performance, and well-being (pp. 251-276). Washington, D.C.: American Psychological Association. doi:10.1037/14641-012

Hair, J. F., Black, W. C., Babin, B. J., Anderson, R. E., \& Tatham, R. L. (1998). Multivariate data analysis. Prentice hall.

Hamsa, H., Indiradevi, S., \& Kizhakkethottam, J. J. (2016). Student academic performance prediction model using decision tree and fuzzy genetic algorithm. Procedia Technology, 25, 326-332. doi:10.1016/j.protcy.2016.08.114

Joreskog, K. G., \& Sorbom, D. (1989). LISREL 7. User's reference guide. Mooresville, IN: Scientific Software.

Karimi, L., \& Meyer, D. (2014). Structural equation modeling in psychology: The history, development and current challenges. International Journal of Psychological Studies, 6(4), 123-133. doi:10.5539/ijps.v6n4p123

Keefe, J. W. (1979). Learning style: An overview. Student learning styles: Diagnosing and prescribing programs, 1, 1-17.

Lay, C. H. (1986). At last, my research article on procrastination. Journal of Research in Personality, 20(4), 474-495. doi:10.1016/0092-6566(86)90127-3

Lee, Y., \& Choi, J. (2013). A structural equation model of predictors of online learning retention. The Internet and Higher Education, 16, 36-42. doi:10.1016/j.iheduc.2012.01.005

Levin, R. I., \& Rubin, D. S. (1998), Statistics for Management, Prentice Hall, 6th Edition, the University of California.

Mishra, T., Kumar, D., \& Gupta, S. (2014, February). Mining students' data for prediction performance. In Proceedings of the 2014 Fourth International Conference on Advanced Computing \& Communication Technologies (pp. 255-262). IEEE.

Mount, M. K., \& Barrick, M. R. (1995). The Big Five personality dimensions: Implications for research and practice in human resources management. Research in Personnel and Human Resources Management, 13(3), 153-200.

Pajares, F., \& Miller, M. D. (1995). Mathematics self-efficacy and mathematics performance: The need for specificity of assessment. Journal of Counseling Psychology, 42(2), 190-198. doi:10.1037/0022-0167.42.2.190

Pardo, A., Han, F., \& Ellis, R. A. (2016). Combining university student self-regulated learning indicators and engagement with online learning events to predict academic performance. IEEE Transactions on Learning Technologies, 10(1), 82-92. doi:10.1109/TLT.2016.2639508 
Peterson, C., Vaillant, G. E., \& Seligman, M. E. P. (1988). Pessimistic explanatory style is a risk factor for physical illness: A thirty-five-year longitudinal study. Journal of Personality and Social Psychology, 55(1), 23-27. doi:10.1037/0022-3514.55.1.23 PMID:3418489

Pintrich, P. R. (2000). An achievement goal theory perspective on issues in motivation terminology, theory, and research. Contemporary Educational Psychology, 25(1), 92-104. doi:10.1006/ceps.1999.1017 PMID:10620384

Pintrich, P. R. (2004). A conceptual framework for assessing motivation and self-regulated learning in college students. Educational Psychology Review, 16(4), 385-407. doi:10.1007/s10648-004-0006-X

Poropat, A. E. (2009). A meta-analysis of the five-factor model of personality and academic performance. Psychological Bulletin, 135(2), 322-338. doi:10.1037/a0014996 PMID:19254083

Richardson, M., Abraham, C., \& Bond, R. (2012). Psychological correlates of university students' academic performance: A systematic review and meta-analysis. Psychological Bulletin, 138(2), 353-387. doi:10.1037/ a0026838 PMID:22352812

Robbins, S. B., Lauver, K., Le, H., Davis, D., Langley, R., \& Carlstrom, A. (2004). Do psychosocial and study skill factors predict college outcomes? A meta-analysis. Psychological Bulletin, 130(2), 261-288. doi:10.1037/00332909.130.2.261 PMID:14979772

Rotter, J. (1966). Generalized expectancies for internal versus external control of reinforcement. Psychological Monographs, 80(1), 1-28.

Ryan, R. M., \& Deci, E. L. (2000). Self-determination theory and the facilitation of intrinsic motivation, social development, and well-being. The American Psychologist, 55(1), 68-78. doi:10.1037/0003-066X.55.1.68 PMID:11392867

Selim, H. M. (2007). Critical success factors for e-learning acceptance: Confirmatory factor models. Computers \& Education, 49(2), 396-413.

Shahiri, A. M., Husain, W., \& Rashid, N. A. (2015). A review on predicting student's performance using data mining techniques. Procedia Computer Science, 72, 414-422. doi:10.1016/j.procs.2015.12.157

Steel, P., Brothen, T., \& Wambach, C. (2001). Procrastination and personality, performance, and mood. Personality and Individual Differences, 30(1), 95-106. doi:10.1016/S0191-8869(00)00013-1

Steele, C. M. (1997). A threat in the air: How stereotypes shape the intellectual identities and performance of women and African Americans. The American Psychologist, 52, 613-629. doi:10.1037/0003-066X.52.6.613 PMID:9174398

Thatte, A. A., Rao, S. S., \& Ragu-Nathan, T. S. (2013). Impact of SCM practices of a firm on supply chain responsiveness and competitive advantage of a firm. Journal of Applied Business Research, $29(2), 499$. doi:10.19030/jabr.v29i2.7653

Tinto, V. (1975). Dropout from higher education: A theoretical synthesis of recent research. Review of Educational Research, 45(1), 95-112. doi:10.3102/00346543045001089

Tinto, V. (1982). Limits of theory and practice in student attrition. The Journal of Higher Education, 53(6), 687-700. doi:10.2307/1981525

Vermetten, Y. J., Lodewijks, H. G., \& Vermunt, J. D. (2001). The role of personality traits and goal orientations in strategy use. Contemporary Educational Psychology, 26(2), 149-170. doi:10.1006/ceps.1999.1042 PMID:11273654

Watson, D. (2000). Mood and temperament. New York, NY: Guilford Press.

Wehmeyer, M. L., Agran, M., \& Hughes, C. A. (2000). National survey of teachers' promotion of self-determination and student-directed learning. The Journal of Special Education, 34(2), 58-68. doi:10.1177/002246690003400201

Weinstein, C., Palmer, A. C., \& Schulte, D. R. (1987). Learning and Study Strategy Inventory (LASSI). Clearwater, FL: H\&H.

Wolters, C., Pintrich, P., \& Karabenick, S. (2003). Assessing academic self-regulated learning. Paper presented at Indicators of Positive Development Conference sponsored by Child Trends. Academic Press.

Wood, R., \& Locke, E. (1987). The relation of self-efficacy and grade goals to academic performance. Educational and Psychological Measurement, 47(4), 1013-1024. doi:10.1177/0013164487474017 
Iti Burman obtained her Bachelor's degree in Computer Applications from Guru Nanak Dev University, India. Then, she obtained her Master's degree in Computer Applications from Guru Gobind Singh Indraprastha University, India and pursuing PhD in IT from Amity University, UP. She is currently working as an Assistant Professor in the IT Department at the Vivekananda Institute of Professional Studies, Rohini, Delhi, India.

Subhranil Som received his Master's Degree in Computer Application in 2003. His PhD in Computer Science and Engineering from reputed Government University, University of Kalyani, West Bengal, India in the year of 2012. He is currently Professor in internationally reputed Amity University, Noida, UP, India. He is empaneled PhD supervisor in the Amity University. He holds a distinction in Physics and Mathematics in Graduation from Jadavpur University, Kolkata, WB, India. His fields of interest include cryptography, network security, information security, e-health, robotics, Core Java, C++, C, etc. He has published more than 50 papers in reputed international, national journals and conferences. He was attached with a WHO's International Research Project on "e-Health for Health Care Delivery", from the University of New South Wales, Sydney, Australia. He has visited Australia, Singapore, Thailand, and the UAE for his academic and research work. He is a member of several professional bodies such as IEEE, IAENG, IACSIT, ISOC, and FOSET. He acted as a chair, reviewer, and TPC member of different international journal and conferences. He has finished several courses related to computer application, object-oriented analysis and design, software engineering, and project management. He has more than 15 years teaching and research experience.

Syed Akhter Hossain is currently the head of Department of Computer Science and Engineering at Faculty of Science and Information Technology, Daffodil International University, Dhaka, Bangladesh.

Mayank Sharma is working as Assistant Professor with Amity Institute of Information Technology, Amity University Uttar Pradesh. He earned his PhD (Computer Applications) from the University School of Information \& Communication Technology, Guru Gobind Singh Indraprastha University, Delhi, Masters in Computer Applications (MCA) from V.V.S Purvanchal University Jaunpur, India, and B.Sc. from D.A.V.(PG) College, Bulandshahar affiliated to CCS University Meerut. He has total 15+ years of experience in the field of Teaching at various positions. His Area of interests are data analytics, soft computing, pattern recognition, information recognition, data warehousing and mining, etc. He has in total 20 publications in Scopus index international conference and international journals. He is member of IEEE, Life member CSI and ISTE. 